\title{
A comprehensive survey of protein palmitoylation in late blood-stage Plasmodium falciparum
}

\author{
Matthew L Jones, Mark O Collins, Jyoti S Choudhary, Julian C Rayner \\ From Parasite to Prevention: Advances in the understanding of malaria \\ Edinburgh, UK. 20-22 October 2010
}

Protein palmitoylation, the addition of a 16-Carbon saturated fatty acid to cysteine residues, is a common posttranslation modification of both peripheral and integral membrane proteins. As a reversible modification, palmitoylation is essential for the dynamic regulation of protein function-controlling, in many cases, protein localisation both to and within specific membrane domains, protein stability, and protein activity. Using two complementary techniques, one relying on the exchange of palmitoyl groups with a biotin linker and the other relying on metabolic labelling of cells with a palmitic acid analogue, we have purified the total catalogue of palmitoylated protein from Plasmodium falciparum schizonts. The use of these two complementary techniques in tandem with SILAC based mass spectrometry to allow robust quantitative MS have allowed the identification of more than 250 palmitoylated proteins in late blood-stage P. falciparum parasites. This represents the first global analysis of protein palmitoylation in any Plasmodium parasite and has identified palmitoyl-proteins involved in protein secretion, protein export, drug resistance, signalling, development, and invasion. Furthermore, we have found that palmitoylation is essential for the completion of the blood-stage life cycle and that this modification directly regulates the stability of at least two proteins essential for invasion, PfGAP45 and PfMTIP.

Published: 20 October 2010

doi:10.1186/1475-2875-9-S2-P16

Cite this article as: Jones et al:: A comprehensive survey of protein

palmitoylation in late blood-stage Plasmodium falciparum. Malaria Journal 2010 9(Suppl 2):P16.

Submit your next manuscript to BioMed Central and take full advantage of:

- Convenient online submission

- Thorough peer review

- No space constraints or color figure charges

- Immediate publication on acceptance

- Inclusion in PubMed, CAS, Scopus and Google Scholar

- Research which is freely available for redistribution 